\title{
Dialectics of Al-Farabi - The Weapon and the Servant of the Scientific
}

\section{Art}

\author{
Muhayyo Kutumbekovna Tulaganova ${ }^{1}$ \\ ${ }^{1}$ National University of Uzbekistan, Uzbekistan \\ Correspondence: Muhayyo Kutumbekovna Tulaganova, University str. 4, Vuzgorodok, 100174, Tashkent, \\ Uzbekistan. E-mail: mtulaganova@mail.ru
}

Received: February 16, 2015 Accepted: April 29, 2015 Online Published: July 30, 2015

doi:10.5539/ass.v11n19p113 URL: http://dx.doi.org/10.5539/ass.v11n19p113

\begin{abstract}
The article "The dialectics of Al-Farabi-the weapon and the servant of scientific art" is devoted to Uzbekistan researchers and their methodology of philosophical discourse, which is built on the active use of the national philosophical heritage, in particular the works of Al-Farabi "Dialectic" and "Path to happiness found". This article parallels between contemporary pragma-dialectical teaching and the art of dialectic as the art of dispute as presented by Al-Farabi.
\end{abstract}

Keywords: pragma-dialectics, discussion, learning method, theology, scientific debate, rhetoric, sophistry

\section{Introduction}

Uzbekistan has been independent for almost a quarter of a century. A whole generation was brought up in a new ideological paradigm. At first, the political, economic projection of independence looked relevant. Yet this moment the problem rather, moved up to the level of philosophical discourse methodology. Despite the fundamental sounding, the task of elaborating one's own methodology has the urgency and relevance. To bring the modern achievements of science closer, in particular, those of political-legal, biomedical, management, educational technologies, to ordinary (folk) consciousness, they must be interpreted based on the traditional categorical apparatus. There are many mismatches between the categorical apparatus of Europe-centered philosophy and domestic (Uzbek) categorical apparatus. It is sometimes difficult to find the equivalent among various concepts. The modern philosophical discourse ideas must be verified through the prism of traditional concepts. National academic circles are involved into the development of their own methodology of philosophical discourse basing on the creative heritage of Uzbek thinkers.

Abu Nasr Muhammad bin Muhammad bin Tarkhan Ibn Uzlog, better known under the name Al-Farabi was born in 873 in Farab area. According to historians, the Farab area was to the northwest of Shasha city (Tashkent). Al-Farabi was born in a military family of Turkic tribe; his early education was in Shasha and Samarkand, studied and worked for some time in Bukhara. At that time, Central Asia was subordinated to the Arabs after protracted wars and became a part of the Caliphate. Baghdad became the cultural centre of the Arab Caliphate, where people, thirsty for knowledge, from all parts of the Caliphate were aspiring for natural science thoughts and philosophies. Al-Farabi also went there to continue his education. The philosophical teachings of Al-Farabi take a special place in the spiritual inheritance of Eastern nations.

His ideas influenced the region's outstanding thinkers, not only in the middle ages but also at the present stage. Each new study discovers unexplored facets of his encyclopedic heritage. Al-Farabi is a representative of the brilliant Pleiades of oriental peripatetic people such as Ibn Sina, Ibn Rushd, Ibn Badzha and others. He was a truly multicultural thinker implicitly, but lived and worked in the era of Islam dominance. Oriental peripatetic school was presented by encyclopedic researchers, that's why Al-Farabi's theoretical heritage is so vast and varied that it is possible to find confirmation or prototypes (the beginnings of) the majority of modern ideas of philosophy, psychology, political science, and art history.

\section{Methodology}

Al-Farabi made a significant contribution to the study of dialectic. He uses dialectic as a method and at least in its three meanings: as a method of understanding the world and the man, as a method of formally logical reasoning, and as the art or the craft of reason. He analyses any event, taking into account such fundamental 
principles of (ontological) dialectic, as the principle of development and the duality of categories. Most commonly, he perceived the category of "dialectic" as a method of dialogic consistent truth search in the way Aristotle suggested it. A man is called "dialectic", he wrote, because of his occupation, the method of reasoning and the ability to apply his art (Al-Farabi, 1985, p. 585).

Arabic lexical meaning of the word "Dialectic" - "Jadal"-is 'dispute', 'argument'. Al-Farabi calls this type of logical art a method, a way of reasoning, knowledge. Al-Farabi understands the art of dialectic as the "art, by which a person acquires the ability to form the syllogism from commonly accepted assumptions for any general theory refutation" (Al-Farabi, 1985, p. 585), which we receive from the answers to the questions during a dialectical discussion. The responding person, in his turn, wants to defend his point of view, which is one of the two parties of the conflict. Al-Farabi defines the dialectic method, not only as a way of question and answer, but as a strategy and tactics of scientific debate, of a dispute, as a result, of the victory over the opponent. The emergence of philosophy itself as a rationalist direction in the Muslim world culture is largely involved in discussions about the issues, concerning questions about the creation of the world and freedom of will, human predestination and responsibility-the discussions caused by theological and legal disputes. M.T. Stepanyants approaches this question very peculiarly, in particular the origin of the universe and its structure, human nature, his moral ideals and ways of truth realization (Stepanyants, 2001). Any form of scientism in the Arab-Muslim medieval culture was defined by religion. Theologians used dialectics, since it relies on the "widely accepted" view and is applied in disputes. A man, trying at any price to take over the partner, can take it. Here not only the flexibility of thinking is meant, Al-Farabi finds another thing important: the dialectic is an important tool of cognition in methodological terms.

Al-Farabi understood dialectic as a skill to contrast various points of view, and to prove one's opinion. He claimed that dialogue helped to determine the truth, which was absent at the beginning of the dispute, but appeared in the process of discussion. Al-Farabi believed that all art types can be divided into two types: 1) art, in which the result is achieved after the accomplishments of certain action without reflection, e.g. spinning art, shoe-making art; 2) art, in which you must first think and reflect, then do some action and only then the result comes, e.g. in medicine, the physician should not necessarily cure the patient, but must apply all his knowledge and efforts to a particular illness for the recovery of the patient. You don't need anything more from a doctor than the treatment of a patient, and if all the medical procedures are followed by the recovery of the patient, it is good, and if not, it does not mean that the doctor is very weak in medicine. Al-Farabi believes dialectic to be the second type of art while apodeictic (Greek рпдейкфйкьт) to be the first type of art.

\subsection{Generally Accepted Assumptions}

In particular, Al-Farabi promotes the doctrine of "common opinions" as primary, immediate knowledge, prior to logical conclusions. Although it is very possible that the generally accepted attitudes can contain lies and, so, you need to check them. Therefore, dialectic is an art closest to the apodictic, as it allows you to rise from just general opinions to the true original source of knowledge.

So, the generally accepted proposition, according to Al-Farabi, is the main category of dialectics art. It includes the assumptions or judgments, which are all from people, all human experience knowledge concentration. The word 'malaka' (Al-Farabi. 1985, p. 585), refers to the ability, the property, and the habit. Al-Farabi uses it as a philosophical term that refers to the innate ability (talent) of the person to mastering all five human syllogistic arts (apodeictic, dialectic, rhetoric, sophistry and poetics), which leads a person to a particular purpose. For example, A. V. Sagadeev believes that the dialectical reasoning that is "mostly true", makes up the core of the debates, dialogues on the basis of probable, "common and well-known" ideas and is used primarily in religious and moral aspects (Sagadeev, 2009). He approaches to the problem in a very specific way.

The first things the person is relying on when he cognizes the world, are: 1) generally accepted views are the views that at the first sight are preferred by everybody; 2) acceptable viewpoints are those in respect of which the person does not have his own knowledge, so he trusts the knowledge of another person he has a good opinion of; 3) sensual perceptions.

\subsection{The Fourth Philosophy}

Al-Farabi believed that in order to make people have a friendly attitude to politicians, they need to do something that brings people the benefit in certain circumstances, because that's exactly what people demand from them.

As they act together in pursuit of the truth, that's how they might also join philosophers in participation in achieving the greatest happiness to the best of their ability. Politicians and scientists suggest knowledge to people because they can't understand it with the help of proofs based on the reliable information. The content of the 
knowledge is hardly accessible for them. And this can only be done with the help of knowledge, shared by everybody. This is reflected in the fact that we appeal to them by using common reasoning, generally accepted by them and used in their interactions with each other. Al-Farabi described this type of training "the fourth philosophy" (Al-Farabi, 1985, p. 585), which is defined as external, outer philosophy. Thanks to this art, the philosopher cooperates (talks) with the public and guides it to the truth. Typically, the public does not accept what it does not understand and condemns it.

Al-Farabi believed that only dialectic could resist sophistic thoughts, and oppose to the sophistic doubt. Opponents always want to confuse him, to interrupt him, to humiliate his work; only a dialectic is able to face sophistic disputes adequately (Aristotle.1978 V. 2 "On the sophistic refutation"). And with the help of the dialectic art, philosophy is protected against Sophists. This is another benefit of dialectics, useful for philosophy (Al-Farabi, 1985, p. 585).

According to Al-Farabi, a dialectic may reach the highest degree in the art of dialectic, only when he is able to exhaust all the means of upholding or refuting dialectical thesis. This is the main task of the dialectics. Here again, Al-Farabi compares a dialectic with a physician who knows medicine well and applies all the medicine means to the patient. This is the task of the doctor-not to achieve the recovery at any cost.

\subsection{The Purpose of the Art of Dialectics}

Victory in the art of dialectic, is not the ultimate goal, it is only the first skills for improvement of dialectics, so it obeys the dialectical actions, which are of use in the sciences. Human perfection in dialectics is similar to the perfection that is achieved in other training arts, due to which victory is achieved. During the dispute, a man begins to acquire the knowledge to defeat the opponent, and at the same time, he can use his knowledge, regardless of whether he is asking or answering. Therefore, both "opponents" should be equal in knowledge in this area and in the art of dialectic mastering. If one of the dispute participants is better than the other in some spheres, his speech becomes arrogant and instructive, because in that case he would try to carry out a study at such a level that even a weak opponent could comprehend.

The strong opponent's speech will be excited, while the weak side will agree to it and take up what he can't reach. Of course, his speech will be weak and uncertain. In this case, neither of the conversation partners will have reached the goal set for themselves, which is training and preparing the mind for sciences.

Consider the situation where the opponents are equal in knowledge and in the art of dialectic, then comparing and contrasting them is not about what they are equal in, but about the superiority of one over the other in the course of this conversation. The cause of the superiority of either of the dispute participants can be wit and insight, and the weakness of the second may be in his being inattentive during the speech; in the end he guessed neither the doubt place nor the objection place. In this case he "misses and lets out without consideration everything which the asking opponent is gaining benefit from" (Al-Farabi, 1985, p. 585). Gradually he is unmasked, his speech is interrupted and he falls silent. But if the answering speech partner guesses right, losing nothing from the conversation, in this case, the questioner does not receive from him what he wants by means of disclosure. The responding partner becomes more confident and does not stop even when making mistakes in his speech, being inattentive, or unduly worried. It can happen that the respondent is too cocky. An example is Prosomakh's speech with Socrates. He was too sure of himself, and did not agree with him and thought that he could refute all the arguments, because he thought that his opponent was so inattentive that never guessed the place for objection, and so he always lost in the dispute to Socrates (Al-Farabi, 1985, p. 585).

Correspondingly, if a person has applied all the knowledge and efforts for making and maintaining a conversation, we can assert that he really knows the art of dialectic. Yet if he loses after he applied every effort that the art of dialectic requires, this does not mean that he is a weak speech partner. This happens because there was no other way out but this one. Finally, he should not always win every dispute. This situation is similar to what happens in other training arts, such as rhetoric, war, medicine, agriculture, etc.

We have already mentioned that the dialectic does not apply to such arts as carpeting, spinning, shoe making, where a carpenter has to make a door, a spinner needs to be able to weave clothes and a shoe-maker has to make shoes, that is all that is required of them. Here one does not need to invent anything new, just needs to do the work without reflections. The art of dialectic requires reflection to implement its objectives, with the increasing demand for them, and it also requires more efforts. The arts, which are self-sufficient, require little reflection. This could include the apodeictic sciences-sciences based on evidence and their position is the same as in carpeting art, and in the other arts, which are self-sufficient. 


\section{Results}

Thus, dialectic is an exercise for a person and is used for communication with other people. With its help, the person becomes ready for science, based on reliable knowledge. Dialectic is a workout, and the art of dialectic is the art of practicing. Here are the parallels between arts, which represent the art of preparing to commit an act, such as the art of physical fight, fencing, etc., in which all actions are contrasted between the two rivals, leaving them with a desire to win. The pleasure, which they get from winning, is the reason for the improvement of these arts and therefore they try to exercise more in order to achieve victory.

Al-Farabi believed that to achieve truth and reliable knowledge, people should enjoy the art, based on the constant exercise; this is dialectics, which can always resist the sophistry. The art of dialectic is useful because it leads to the truth, it is a tool and a servant of reliable knowledge. Only dialectics leads human mental activity, sends it to the reliable knowledge and warns against the verbal tricks (sophistry). Dialectic is not just the art of disputing, its goal is the mind improvement. An important place is taken by systematic, careful analysis of all the assumptions and opinions, finding contradictions that lead to reliable knowledge.

\section{Discussion}

For example, according to A. Schopenhauer, the essence of the dispute is based on the premise, which is to be confuted. There are two ways of doing this: in the first, we refute the absolute or objective truth of the theory, proving the disagreement with these characteristics, which distinguish the subject in question. In the second, we refute the relative truth of the thesis, arguing that the latter is contrary to other opinions or views of an opponent, or refutes his argument. The goal can be achieved in two ways: directly or indirectly. By the first way, we attack the original thesis, by the second-we attack its results. The first way proves the unfairness of the argument, and the second way proves that this thesis may not be truthful. Opinions of the conversation participants represent one of the parties of the conflict; it is not by chance that Schopenhauer calls the dialectic a "spiritual struggle".

In ancient times, the person presenting any new ideas, had to do it publicly in front of influential people. There he was to answer all the questions of his opponents and defeat their arguments with his proofs. The losers in public disputes were executed or provided the opportunity to accept the arguments of the winning side and accept their faith. The disputes not always occurred between people-entire monasteries took part in it, and due to the failure in the dispute they could disappear despite their long existence and history. The right of eloquence and logical evidence was absolutely beyond controversy-no one could escape from the call to the dispute. (Vasilyev, 1981). In modern science, dispute problems receive little attention. Still some of the dispute characteristics appear in the dialogue system. S. Humblin and V. Steltzner do a special study of this aspect. Results of these authors' research are taken into account when the modern theory specifies the argumentation.

However, post-modernist thinkers, e.g. Foucault, claimed: "It is impossible to make anyone speak the millennial language of dialectics" (Foucault, 1994, p. 129), because dialectics is the language of contradiction. Is dialectics outdated? The relevance of this work is to refute such allegations, to prove that the teaching of dialectic is in demand like never before. The western philosophical thought itself provides arguments in defense of the dialectics and rhetoric; there appeared the studies, which are naturally the revival of ancient dialectic. These are the works of S. Tulmin, Frans Kh. van Eemeren (2002) "Advances in pragma-dialectics", Robert Grootendorst, Francisc Snuck Henkemans (2002) Argumentation: analysis, verification and reporting, Kh. Perelman and L. Olbrehts-Tytekoj. Some authors call them 'pragma-dialectical teaching' (others write "pragmadialectic doctrine"), a new theory of reasoning, or a new rhetoric. They are the application of dialectics in modern philosophical discourse, although Y. V. Ivlev seems to be right, saying that "the general theory of reasoning does not exist: only the basics of logical argumentation theory have been developed "(Ivlev, 1997, p. 54). According to the contemporary philosophers, abstract formal logic "does not work" without the techniques of the "new" rhetoric, which foundations, meanwhile, go back to antiquity. The pragma-dialectical theory is applied to understand different types of contentious talk. Studies in this direction explain the highly theoretical need for a new reading of dialectics in the peripatetic statement and interpretation, whose leader is Al-Farabi, at least for Central Asian explorers, who are able to read Al-Farabi's work on the dialectics in the original language.

\subsection{Pragma-dialectics}

Supporters of the so-called pragma-dialectical teaching claim that they finally managed to close the gap between logic, dialectics, rhetoric. According to Al-Farabi, it is: 1) scientific, 2) dialectical, 3) sophisticated methods. The new theory lacks the rigor of formal logic, when the goal is not search for truth, but the strict adherence to the rules of the knowledge. It preserves the consistency of dialectics, and emotional conviction, expressed in the rhetorical battles, helps, rather than hinders, the search for the truth. Meanwhile, this gap did not exist for Al-Farabi, therefore, in our view, "bridging the gap" between formal logic, dialectic and rhetoric cannot be 
considered an achievement. This is the art of dialectic in three dimensions, while pragma-dialectics supporters claim that it takes an intermediate position between the two traditional approaches: the logical and rhetorical ones (Karpov, 2013). The basic principles of dialectics defined the marginal status.

\subsection{Views of Al-Farabi}

In our view, dialectic is at the core of the formal logic rules and rhetoric means. For example, repeating his ideas about the dialectic as "a training ability", Al-Farabi repeatedly stressed the need to respect the laws of formal logic, that is, established a relationship of dialectics and logic. Al-Farabi argued that the aim of the reasoning is evidence, search for truth, not being convinced of his rightness, that the purpose of the discussion is to identify contradictions and inaccuracies in judgements, not just to identify them, and, most importantly, to overcome them. Dialectic is needed when you want to understand what seems to be reliable, but it is not so in reality, i.e. the rhetoric is needed not in itself, but to establish the truth, otherwise it becomes an "imitation of dialectics" (Al-Farabi, 1985). Al-Farabi did not identify dialectic and rhetoric, he even devoted different treatises to them: he has a work Dialectics" and a work "Rhetoric".

According to Al-Farabi, a dialectic talk is a refutation and a proof, because it requires not to move from the chosen topic of discussion. Two more participants, two arguing parties need to be included: "Such a conversation does not need more (participants), than two" (Al-Farabi, 1985, p. 585). A dispute participant must adamantly defend his opinion, using all more and more new ways, or deny without any shade of doubt. A very stressful competition occurs between the parties of the dispute. Dialectical debate takes place on the basis of the dialectical method, and has a form of a dialogue. The successful contest brings fun to the dialectic discussion participants, but on condition that both disputers have equal ability to dispute and the same knowledge of the dialectic art. Regardless of victory or defeat, both members of the dialectical dispute, according to Al-Farabi, derive the equal benefit from it. The rivals become stronger in their beliefs, and this is the best way to separate truth from falsehood. Al-Farabi wrote: "It is certain that there are no more compelling, useful and powerful arguments than evidence of different knowledge about the same things and many opinions united into one, everybody's intellect serves as an evidence" (Al-Farabi, 1970, p. 395). Hence, there is another new point, continuing the idea that cognitive contest is transformed into cooperation, and victory in a dispute is replaced with the general opinion. The idea of dialogical dispute-rivalry of two people becomes a teaching about many people's views collaboration, based on the reliable knowledge.

\subsection{About Common Sense}

Al-Farabi subjected non-dialectical thinking, he calls him "sophistic" to serious criticism and gave methodological advice concerning how to differentiate it from the dialectical: "Since the middle falls between the two extremes, in one of the extremes you can find something like the norm or the middle, and you should watch out for extremes, similar to the middle" (Al-Farabi. 1973, p. 395). He understands dialectics as a way of thinking to be reasoning not in the formula "either/or", but in the unity of the opposite sides of the phenomenon, although their unity may take the form of conflict, up to the mutual exclusion. A stiff opposition, the absolute gap between the alternatives and selecting one of them as a priority, for example, in the social sphere, in particular in the political one, in our view, are fraught with dangerous consequence. We would like, in this regard, to recall "prudence", the need for which was repeatedly pointed out by Al-Farabi. Still he excused the human inability for common sense: "Everyone, I say, from the beginning of his existence, has the natural ability, thanks to which his actions, soul affects and sanity are exactly as they should be and they should not be" (Al-Farabi, 1973, p. 395). Here is the need to practice the art of dialectic. In the treatise "Specifying the path to happiness" he writes: "Something due to which a person has a temper/character or changes one temper for another, the tempo he comes into contact with, is the habit. I mean the habit to be a frequent, lengthy repetition of some single action" (Al-Farabi, 1973, p. 395). Moreover, claiming temper/moral to be the established habit, Al-Farabi emphasizes the dialectics of these categories, the possibility of their mutual transition: "When a person does not possess certain character, then touching the good or bad temper, he can voluntarily move to the opposite character" (Al-Farabi, 1973, p. 395).

Another valuable moment of Al-Farabi dialectics teachings is the statement concerning a dialog form of dialectic existence. He writes: "The art of dialectic is what gives a person the ability (force), therefore, a person can attain truth or philosophy only by developing the ability for dialectical debate" (Al-Farabi, 1985, p. 585). For Al-Farabi the search for truth is not a goal, but also the communication process; communication should not separate people, it should unite them for the sake of the truth. Still this aspect of dialectics is quite distorted. If to trust A. Schopenhauer, dialectic is the art to debate, to dispute and to talk (Schopenhauer, 2000). Bringing dialectic to eristic waters down the essence of the dialectic, which is not only the art of arguing, but also a way of thinking 
and reasoning, without possession of which you cannot defeat the opponent: "And this is possible only if the mind has the ability to establish doubtful places, and this, in turn, is possible only through the art of dialectic" (Al-Farabi, 1985, p. 585).

\subsection{Conclusions}

Thus, on the basis of Al-Farabi's work "Dialectic", it can be stated that in the process of reasoning, one can't take formal logic, dialectic, and rhetoric (eristic) separately. Only as a whole they can serve as a credible method of cognition in the process of reasoning. It is necessary to recover their unity-this is the goal new theories of argumentation and pragma-dialectics have. Al-Farabi relates the art of dialectic to philosophy, which aims at developing the ability of the mind to find questionable places and to find the truth. Dialectics prepares the person for doing the theoretical science, based on reliable knowledge and for making the right decisions in everyday life. Yet for this, person needs such abilities (advantages) as prudence, cleverness and ingenuity. These abilities help the person to find the correct dialectical assumptions in what people usually disagree about. The human mind in many cases is not intentionally mislead, but "due to being unaware', and therefore a person should be put in a position in which he would have faced a contradiction in judgement, and would be able to properly solve them. One needs to bring up such human qualities and abilities through which the person could distinguish good from evil, the beautiful from the ugly, etc.

According to Al-Farabi, the purpose of philosophy is to achieve happiness and the purpose of dialectics is the achievement of the perception of human mind the philosophy comprehension. The purpose of the dialectic art is to support the art philosophy and to serve it. If the beginnings of philosophy are considered to be the first true general premises, based on reliable knowledge, so the beginnings of dialectics are common general premises.

\section{Summary}

In conclusion, I would like to repeat that the methodological and philosophical principles proper look more credible if their support grew on the national grounds, and the Uzbek researchers have a solid theoretical heritage that allows to do this, e.g. Al-Farabi's creative works. His methodology is helping domestic researchers find their way into many modern discussion questions. His teaching is a product of the medieval era, which creatively combined everything of value that was in the previous logical systems. He learned Aristotle's ideas thoroughly and not only managed to compile, but also to develop this science. Al-Farabi's ideas were further developed in the works of his followers-eminent thinkers Ibn Sina, Ibn Rushda and others.

I believe that the future belongs to the dialectics. I think that the philosophical heritage of Al-Farabi may play an important role in the study of scientific disputes efficiency as well as in the development of discussions and argumentation theory common problems. We should address our roots more. The scientific and philosophical teachings of our ancestors are as relevant as ever today. One of the unpleasant moments in Al-Farabi's philosophy study was that few people were familiar with his works. Even if somebody heard of him, then only as of a Greek treatises' commentator, in which he was just a translator who was simply retelling, refining and explaining. The reality is far from it: Al-Farabi was the forefather of Islamic philosophy, spoke more than 70 languages, was an excellent musician, doctor, philologist, psychologist. Al-Farabi believed that philosophical knowledge has a universal nature, it is universal for all peoples and develops in the appropriate conditions (Al-Farabi "On the origin of philosophy"). In his works, he tries to convey his philosophical (metaphysical) truth in an accessible form to the possibly broader segments of society. In his view, this can only be achieved with the help of exoterism, that is, to make the vocabulary style lower, to make it clear for the uninitiated audience. G. B. Shajmukhambetova speaks about the same in her work "A perfect philosopher as holder of the knowledge reaches the top of sophistication when he cares about acceptable ways of transferring knowledge to others" (Shajmukhambetova, 1979). For example, Khatami also gives him high praise: (Al-Farabi planted a sapling, which, thanks to the thoughtful care of his wise followers, turned into a mighty tree with time and gave many fruits..." (Khatami, 2001). No wonder he is called the "Aristotle of the East" for his encyclopedic knowledge and his profound insight in understanding the ideas of the great Greek philosophers, such as Plato and Aristotle. It is known that Abu Ali ibn Sino, admired this great mentor. Besides the usual praise he openly stated that his understanding of Aristotle's ideas about metaphysics was formed thanks to the works of Al-Farabi: "I read a book called "Metaphysics", but did not understand anything, and its author's intentions remained hidden to me," until he found Al-Farabi's comment to Aristotle's "Metaphysics". (Materials on the history of progressive social-philosophical thought in Uzbekistan, 1975.)

Undoubtedly, Al-Farabi's place and importance in world history is underestimated because he should rightfully take his place among such great philosophers as Aristotle, Plato, Hegel and others. 
We remember with gratitude the contribution of academician M. M. Khairullaev, who was the greatest scientist of the Uzbek authors who explored the logical-philosophical heritage of Al-Farabi, and the founder of Farabi researches in Uzbekistan. His scholarly works are concentrated on Al-Farabi philosophical heritage: (1) Khairullaev M. 1973. Farabi is the largest medieval thinker; 2) Khairullaev M. (1975). Farabi. Age and teaching), his monograph (1966), Khairullaev M. Farabi's worldview and its importance in the history of philosophy), and numerous scientific articles are theoretical foundation in the study of Al-Farabi's philosophy in Uzbekistan. His students are the followers of his teachings: Mutalibov S. A. (1981) and Faizikhodzhaeva D. E. (2000). We are the third generation students. To date, more than half of the creative heritage of Al-Farabi hasn't been studied, so Uzbekistan philosophers face a huge task of exploring this huge material and our task is to make every effort to implement Al-Farabi's ideas into life.

\section{References}

Al-Farabi. (1970). Philosophical treatises (p. 395) Almaty: Nauka.

Al-Farabi. (1973). Specifying the path to happiness. Socio-ethical treatises (p. 395). Almaty: Nauka.

Al-Farabi. (1985). Historical and philosophical treatises. Dialectic (p. 585). Almaty: Nauka.

Aristotle. (1978). On the sophistic refutations. Moscow, Nauka.

Faizikhodzhaeva, D. E. (2000). The problem of evidence in logical exercises of Central Asia thinkers. Tashkent, Uzbekistan.

Foucault, M. (1994). On transgression. Eros Tanatographia. Georges Bataille and the French thought of the mid-twentieth century (p. 129). Spb.

Grootendorst, R., \& Henkemans, F. S. (2002). Argumentation: analysis, verification and reporting.

Ivlev, Y. V. (n. d.). Basics of logical argumentation theory (p. 54). Retrieved from http://iph.ras.ru/uplfile/logic/ $\log 10 /$ Li_10_Ivlev.pdf

Karpov, G. V. (n. d.). Pragma-dialectical approach. The basic principles. Retrieved from http://rhetoric2013. blogspot.ru/2013/12/4.html

Khairullaev, M. (1973). Farabi is the largest medieval thinker. Tashkent, Uzbekistan.

Khairullaev, M. (1975). Farabi Age and exercise. Tashkent, Uzbekistan.

Khatami, S. M. (2001). Tradition and Thought under authoritarianism. Moscow Publishers of the Moscow university.

Materials on the history of progressive social-philosophical thought in Uzbekistan. (1975).

Mutalibov, S. A. (1981). Logical teachings of Al-Farabi. Tashkent, Uzbekistan.

Sagadeev, A. V. (2009). East peripatetism. Moscow Publishing house Marzhani.

Schopenhauer, A. (2000). Eristic, or the art of winning in disputes.

Shajmuhambetova, G. B. (1979). Al-Farabi Abu Nasr and the formation of philosophical knowledge in the medieval Middle East. Moscow

Stepanyants, M. T. (2001). Eastern philosophy. Moscow East literature.

van Eemeren, F. H. (2002). Advances in pragma-dialectics.

Vasilyev, V. (1981). Buddhism and its tenets, history and literature. Moscow, Nauka.

\section{Copyrights}

Copyright for this article is retained by the author(s), with first publication rights granted to the journal.

This is an open-access article distributed under the terms and conditions of the Creative Commons Attribution license (http://creativecommons.org/licenses/by/3.0/). 